\title{
DRYING OFF METHODS, PARITY AND STAGE OF LACTATION INFLUENCES ON MILK PRODUCTION, MILK COMPOSITION AND SOME BLOOD PLASMA PARAMETERS IN HOLSTEIN FRIESIAN COWS
}

\author{
R.A. Abou-Saleh, A. S. M. Soliman, M. R. El-Mahdy and T. M. M. Hassan* \\ Department of Animal Production, Faculty of Agriculture, Benha University, Egypt \\ Corresponding author: tamer.mohamed@fagr.bu.edu.eg
}

\section{SUMMARY}

The aim of this study was to investigate influence of drying off methods, parity number and stage of lactation on milk production, composition and some blood plasma parameters by using 27 Holstein-Friesian cows which divided into three groups (each group contained 9 cows). First group was dried by suddenly stop milking method, second group dried by irregular milking method and third group dried by the incomplete milking method in different parities. Total milk production of the next lactation was recorded and also average daily milk yield during ten months of lactation. Milk and blood samples were taken from all cows every 100 days during the lactation season to analyze some milk composition and blood plasma parameters. Results showed that drying off cows by the incomplete milking method before calving gained higher milk production, better milk composition and blood plasma parameters than other drying off methods but not significantly. Fourth or more parity cows gained higher milk production, milk composition and blood parameters than other parties. Cows at the third stage of lactation (last 100 days) had the highest milk composition and blood plasma proteins (total protein albumin and globulin). In conclusion, incomplete, irregular and sudden stop milking can safely be recommended as a method for drying off cows producing at least up to 20, 11-20 and >10 kg daily, respectively without negative results in quantity and quality of milk as well as blood plasma parameters. It could be recommend that using sudden stop method for low lactating cows (less than $10 \mathrm{~kg}$ milk/day) and irregular and incomplete methods for both medium and high lactating cows (11-20 kg and more than $20 \mathrm{~kg}$ milk/day, respectively).

\section{Keywords: Drying off methods, Holstein Friesian, Milk, Blood parameters}

\section{INTRODUCTION}

The dry period is a crucial phase in the lactation season of a dairy cow. Dairy managers aim to dry off pregnant cows to achieve a dry period of appropriate length to maximize productivity in the next lactation season (Dingwell et al., 2001). A dry period of sixty days has been routinely recommended. In recent years, growing interest has developed toward shorter dry period as a management strategy which could be more appropriate for today's high producing dairy cows (Santschi et al., 2011) and is well known to maximize milk production in the next lactation season (Van Knegsel et al., 2014). Shortening the dry period has been proposed as a management strategy to improve the energy balance of dairy cows in early lactation stage. Cows with a short dry period produced $1.4 \mathrm{~kg}$ /day less milk than cows with a conventional dry period (60 days), with average milk yield loss of $4.5 \%$ in the next lactation season. When the dry period was omitted, cow produced $5.9 \mathrm{Kg}$ /day less milk yield than cows with a conventional dry period, with an average milk yield loss of $19.1 \%$ (Steeneveld et al., 2014). The primary factors to be considered in a comparison of drying methods for cows are the effects upon the cow, the time required to drying up the cow and the quantity and quality of milk yielded in subsequent lactations (Wayne et al., 1933). However, optimal dry period length may vary depending on parity number, herd size, and level of milk production, among other factors (Atachi et al., 2013). It is known that milk production is affected by factors such as parity number, stage of lactation and the dry period of cows. The same factors might have some effects also on milk composition and blood parameters in lactating cows (Cozzi et al., 2011 and Kuhn et al., 2007).

The aim of this study was to investigate the effect of drying off methods and parity on the daily and total milk yield, its composition as well as blood plasma parameters and the effect of different stages of lactation on the milk composition as well as blood plasma parameters of imported Holstein Friesian cows in the Nile delta of Egypt.

\section{MATERIALS AND METHODS}

The experimental work of this study was carried out at El-Tonsy (International Company for Animal Wealth) dairy cattle farm in Abou-Rawash, Giza, Egypt, from July 2014 to June 2015 under the supervision of Animal production department staff, Faculty of Agriculture, Benha University.

\section{Management of experimental animals:}

In this study 27 Holstein-Frisian cows of the herd allowed to feed on Egyptian clover (Trifolium alexandriunm), corn silage and rice straw during autumn and winter months. However, in spring and summer 


\section{Methods of drying off cows:}

27 Holstein-Frisian cows were divided into three groups (each group containing 9 cows), first group dried by suddenly stop method, second group dried by irregular milking method and third group was dried by incomplete milking method in different parities which can be illustrated as following:

1. Sudden stop milking drying off method: feeding cows low production concentrate mixture before week of sudden stop milking method till drying.

2. Irregular milking drying off method: at the final week of lactation, cows are milked once per day to decline milk production till drying.

3. Incomplete milking drying off method: at the final week of lactation, cows milked incompletely to decline milk production till drying.

After the final milking, cow's teat was injected by antimicrobial (dry cow therapy) and wax material to protect the udder from invading bacteria during the dry period in all different drying studied methods. All used previous methods were, according to Wayne et al. (1933).

\section{Milk yield:}

The experiment was designed to study the effect of both drying off methods (sudden stop, irregular and incomplete milking) and parity number (second, third and fourth or more parity) on experimental cows (N $=27$ ) average daily and total milk yield. Total milk yield was calculated by summing up of cows daily milk yield during 10 months of lactation.

\section{Milk sampling and analysis:}

Milk samples were taken from all experimental cows $(\mathrm{N}=27)$ every 100 days during lactation to estimate the effect of lactation stage (100, 200 and 300 days of lactation) on milk composition. Milk samples were stored at $5^{\circ} \mathrm{C}$ for subsequent analysis of milk composition (total solids, fat, solids not fat, protein, lactose and ash \%) according to IDF (1991a), IDF (1991b), IDF (1993) and AOAC (1995).

\section{Blood sampling and analysis:}

Blood samples were collected individually every 100 days from all experimental cows $(\mathrm{N}=27)$ during lactation to estimate the effect of lactation stage (100, 200 and 300 days of lactation) on some blood plasma parameters, by addition of EDTA into dry clean tubes. The blood plasma was obtained by centrifuging the blood samples soon after collection at $3000 \mathrm{rpm}$ for 15 minutes. Blood plasma was transferred into vials and stored in deep freezer at -20 ${ }^{\circ} \mathrm{C}$ for subsequent specific chemical analysis. Total protein, albumin, globulin, $\mathrm{A} / \mathrm{G}$ ratio, triglyceride, total cholesterol, calcium, potassium and magnesium concentration were determined according to Henry (1964), Doums et al. (1971), Frings et al. (1972) and American Association for Clinical Chemistry (1977). The concentration of total globulin in each sample was obtained by subtracting albumin concentration from the total protein concentration and albumin globulin $(\mathrm{A} / \mathrm{G})$ ratio was calculated by total albumin by total globulin.

Table 1. Feed ingredients and chemical composition of the experimental diets

\begin{tabular}{|c|c|c|c|c|}
\hline Item & $\begin{array}{c}\text { Early dry } \\
\text { period cows }\end{array}$ & $\begin{array}{c}\text { Close up } \\
\text { period cows }\end{array}$ & $\begin{array}{c}\text { Mediate and low } \\
\text { production }^{2}\end{array}$ & $\begin{array}{c}\text { Fresh and high } \\
\text { production }^{3}\end{array}$ \\
\hline \multicolumn{5}{|l|}{ Ingredients\%: } \\
\hline Corn grain dent yellow & 43.5 & 43.4 & 47.6 & 42 \\
\hline Wheat bran & 26.7 & 19.5 & 21.5 & 18.3 \\
\hline Soybean meal 44\% & 25.8 & 25 & 20.5 & 28.1 \\
\hline Limestone ground & 2 & 2.3 & 1.2 & 1.17 \\
\hline Molasses cane & - & 3 & 6.5 & 3.6 \\
\hline Protected fat & - & 0.6 & - & 3.5 \\
\hline Sodium chloride & 0.9 & 0.275 & 0.7 & 0.6 \\
\hline Vitamins AD3E & 0.175 & 0.2 & 0.15 & 0.15 \\
\hline Sodium bicarbonate & - & - & 1.22 & 1.5 \\
\hline Magnesium oxide & - & - & 0.25 & 0.45 \\
\hline Micro minerals ( $\mathrm{Zn}-\mathrm{Cu}-$ Selenium) & - & 0.1 & - & 0.05 \\
\hline Di-calcium phosphate & 0.225 & 0.35 & - & 0.2 \\
\hline Antitoxins & 0.35 & 0.12 & 0.075 & 0.075 \\
\hline Dried yeasts & - & 0.009 & - & 0.003 \\
\hline Minerals & 0.35 & 0.4 & 0.3 & 0.3 \\
\hline Acid buffer & - & 0.54 & - & - \\
\hline Calcium chloride & - & 1.4 & - & - \\
\hline Magnesium sulfate & - & 2.8 & - & - \\
\hline Total & 100 & 100 & 100 & 100 \\
\hline \multicolumn{5}{|l|}{ Chemical composition $\%$ : } \\
\hline Dry matter & 92 & 90 & 90 & 92 \\
\hline Crude protein & 18.6 & 17.4 & 16.2 & 18.5 \\
\hline Crude fiber & 4 & 3 & 3.5 & 3 \\
\hline Nitrogen free extract & 73 & 70.7 & 76.2 & 73.6 \\
\hline Ether extract & 0.4 & 0.7 & 0.3 & 0.5 \\
\hline Ash & 4 & 8.5 & 3.8 & 4.4 \\
\hline
\end{tabular}

${ }^{1}$ before 21 days of calving, ${ }^{2}$ below $25 \mathrm{Kg}$ milk production cows, ${ }^{3}$ over $25 \mathrm{Kg}$ milk production cows. 


\section{Statistical analysis:}

Statistical analysis was carried out by using the least squares procedure for analyzing the data with unequal subclass number described by SAS (2004). The Statistical models used as follows:

$\mathrm{Y}_{\mathrm{ijk}}=\mu+\mathrm{M}_{\mathrm{i}}+\mathrm{P}_{\mathrm{j}}+(\mathrm{MP})_{\mathrm{ij}}+\mathrm{b}_{1}\left(\mathrm{\times}_{1 \mathrm{ij \textrm {k }}}-\overline{\mathrm{X}}_{1}\right)+\mathrm{b}_{2}\left(\mathrm{\times}_{2 \mathrm{ijk}} \mathrm{x}^{-}\right.$

$\left.\bar{X}_{2}\right)+\mathrm{b}_{3}\left(\mathrm{X}_{3 \mathrm{ijk}}-\bar{X}_{3}\right)+\mathrm{b}_{4}\left(\mathrm{x}_{4 \mathrm{ijk}}-\bar{X}_{4}\right)+\mathrm{e}_{\mathrm{ijk}}($ Model 1)

sWhere: $\mathbf{Y}_{\mathrm{ijk}}=$ the observation of 1 cow average daily and total milk yield; $\boldsymbol{\mu}=$ the overall mean of all observations; $\mathbf{M}_{\mathbf{i}}=$ the fixed effect due to I $\mathrm{I}^{\text {th }}$ drying method $(\mathrm{i}=1,2,3$ where $1=$ sudden stop method, $2=$ irregular milking method and $3=$ incomplete milking method); $\mathbf{P}_{\mathbf{j}}=$ the fixed effect due to the $\mathrm{j}^{\text {th }}$ Parity number $(j=1,2,3$ where $1=$ second, $2=$ third and $3=$ fourth or more parity); $(\mathbf{M P})_{\mathrm{ij}}=$ the fixed effect of the interaction between drying method and parity number; $\mathbf{b}_{\mathbf{1}}=$ Linear regression coefficient of average daily and total milk yield on dry period length; $\mathbf{b}_{\mathbf{2}}=$ Linear regression coefficient of average daily and total milk yield on cow weight at dry period; $\mathbf{b}_{\mathbf{3}}=$ Linear regression coefficient of average daily and total milk yield on cow weight at calving; $\mathbf{b}_{\mathbf{4}}=$ Linear regression coefficient of average daily and total milk yield on cow weight after 50 days of lactation; $\mathbf{e}_{\mathbf{i j k}}=$ random error associated with the individual observation and assumed to be (N, IND) and $\left(0, \sigma^{2}{ }^{2}\right)$. $\mathrm{Y}_{\mathrm{ijkl}}=$

$$
\mu+\mathrm{M}_{\mathrm{i}}+\mathrm{P}_{\mathrm{j}}+\mathrm{S}_{\mathrm{k}}+(\mathrm{MP})_{\mathrm{ij}}+(\mathrm{MS})_{\mathrm{ik}}+(\mathrm{PS})_{\mathrm{jk}}+(\mathrm{MPS})_{\mathrm{ijk}}+\mathrm{e}_{\mathrm{ijk}}
$$$$
\text { (Model2) }
$$

Where: $Y_{\mathrm{ijk}}=$ the observation of 1 cow milk composition and blood parameters; $\mu=$ the overall mean of all observations; $M_{i}=$ the fixed effect due to $\mathrm{I}^{\text {th }}$ drying method $(\mathrm{i}=1,2,3$ where $1=$ sudden stop method, $2=$ irregular milking method and $3=$ incomplete milking method); $P_{j}=$ the fixed effect due to the $j^{\text {th }}$ Parity number $(j=1,2,3$ where $1=$ second, $2=$ third and $3=$ fourth or more parity); $S_{k}=$ the fixed effect due to the $\mathrm{k}^{\text {th }}$ stage of lactation $(\mathrm{k}=1,2,3$ where $1=1^{\text {st }}$ stage, $2=2^{\text {nd }}$ stage and $3=3^{\text {th }}$ stage of lactation); (MP $)_{\mathrm{ij}}=$ the fixed effect of the interaction between drying method and parity number; $(\mathrm{MS})_{\mathrm{ik}}=$ the fixed effect of the interaction between drying method and stage of lactation; $(\mathrm{PS})_{\mathrm{jk}}=$ the fixed effect of the interaction between parity number and stage of lactation; (MPS) $)_{\mathrm{ijk}}=$ the fixed effect of the interaction among drying method, parity number and stage of lactation; $\mathrm{e}_{\mathrm{ijk}}=$ random error associated with the individual observation and assumed to be (N, IND) and $\left(0, \sigma_{\mathrm{e}}^{2}\right)$.

Tests of significance for differences between means were carried out according to Duncan (1955).

\section{Estimating the curve parameters of milk yield:}

In this work, the shape of the milk curve of Holstein cows was studied using the gamma type function (Wood, 1967) which was described as sufficiently good for modeling extended lactations (Abdel-Salam et al., 2011). The following gammatype function was used for describing the lactation curve of all parameters:

$$
\mathrm{Y}_{\mathrm{n}}=a n^{\mathrm{b}} \mathrm{e}^{-\mathrm{cn}}
$$

Where: $\mathbf{Y}_{\mathbf{n}}$ is the daily milk yield $(\mathrm{kg})$ in the $\mathbf{n}^{\text {th }}$ day of lactation, $\mathbf{a}$ is the initial yield, $\mathbf{b}$ describing the rate of milk yield increase up to the peak during the ascending phase, $\mathbf{c}$ describes the rate of milk yield decrease during the descending phase and $\mathbf{e}$ is the base of natural logarithms. The constants $\mathbf{a}, \mathbf{b}$ and $\mathbf{c}$ were calculated by using a general linear model (GLM) procedure of SAS software (SAS, 2004).

\section{RESULTS AND DISCUSSION}

\section{Milk production of cows:}

\section{Drying off methods effect on milk production:}

Cows dried by incomplete milking method had a higher daily and total milk yield $(10889.85 \mathrm{~kg})$ than that dried by irregular $(10187.45 \mathrm{~kg})$ or sudden stop $(9786.01 \mathrm{~kg})$ milking methods as shown in Table (2) and Figure (1). The differences between means of experimental cow's milk yield, due to drying methods effect, were not significant except at daily milk yield at $2^{\text {nd }}$ month of lactation $(\mathrm{P}<0.05)$. In this respect, Wayne et al. (1933) using three methods of drying off Holstein cows, found that complete cessation of milking can safely be recommended as a method for drying off cows producing at least up to $8.8 \mathrm{~kg}$ daily; cows can be dried off in less time by this method than by either of the other two methods considered and they did not record any significant difference in the quantity of milk in the lactations following the drying up of cows by the three methods used (incomplete milking, intermittent milking and complete cessation). Zadeh and Mohit (2013) found that Holstein cows that had the lowest dry period (010days) produced the lowest milk yield (5472.4 $\mathrm{kg} / 305$ days), however, cows that had the medium dry period (51-70 days) produced the highest milk yield $(7518.9 \mathrm{~kg} / 305$ days), while, cows had the highest dry period $(71>130$ days $)$ produced the medium milk yield $(6846.4 \mathrm{~kg} / 305$ days $)$ with significant differences $(\mathrm{P}<0.05)$. Van Knegsel et al. (2014) showed that in Holstein-Friesian cow; milk yield was $13.8,7.7$ and $0.1 \mathrm{~kg} /$ days, for dry period 0 , 30 and60 days, respectively; the study indicated that a reduced dry period ( 30 or 0 days), compared with a conventional dry period of 60 days, reduced the production of milk $(\mathrm{P}<0.05)$. Useni et al. (2014) found that dry period less than 60 days reduced milk yield, while an extended dry period (more than 121 days) may result in over conditioned dry cows and therefore be costly to the dairy farmer even although milk yield is higher in the next lactation.

Regression coefficients of the equation of Wood lactation curve showed that different drying off methods had a different $(\mathrm{P}<0.05)$ a, $\mathrm{b}$ and $\mathrm{c}$ parameters (Table 3). Incomplete, followed by irregular and then sudden stop milking begin lactation season with higher $(\mathrm{P}<0.05)$ milk production (Figure 1). However, incomplete milking obtained a higher $(\mathrm{P}<0.05)$ rate of increased milk production with less persistence of milk yield and 
more c value compared to both of irregular and and c values. sudden stop milking, which almost had the same b

Table 2. Least-squares means and standard errors of experimental cow's average daily and total milk yield during 10 months of lactation

\begin{tabular}{|c|c|c|c|c|c|c|c|c|c|c|c|c|}
\hline $\begin{array}{c}\text { Classific } \\
\text { ation }\end{array}$ & $\mathbf{N}$ & $\begin{array}{c}\text { ADM } \\
\text { Y1 }\end{array}$ & $\begin{array}{c}\text { ADMY } \\
\mathbf{2} \\
\end{array}$ & $\begin{array}{c}\text { ADM } \\
\text { Y3 } \\
\end{array}$ & $\begin{array}{c}\text { ADM } \\
\text { Y4 }\end{array}$ & $\begin{array}{c}\text { ADM } \\
\text { Y5 }\end{array}$ & $\begin{array}{c}\text { ADM } \\
\text { Y6 }\end{array}$ & $\begin{array}{c}\text { ADM } \\
\text { Y7 } \\
\end{array}$ & $\begin{array}{c}\text { ADM } \\
\text { Y8 } \\
\end{array}$ & $\begin{array}{c}\text { ADM } \\
\text { Y9 }\end{array}$ & $\begin{array}{c}\text { ADM } \\
\text { Y10 }\end{array}$ & TMY \\
\hline $\begin{array}{l}\text { Drying } \\
\frac{\text { off }}{\text { methods }}\end{array}$ & & & & & & & & & & & & \\
\hline $\begin{array}{l}\text { Sudden } \\
\text { stop }\end{array}$ & & $26.58 \pm$ & $32.18^{\mathrm{ab}} \pm$ & $33.86 \pm$ & $32.34 \pm$ & $31.14 \pm$ & $29.39 \pm$ & $30.10 \pm$ & $30.39 \pm$ & $28.71 \pm$ & $29.42 \pm$ & $9786.01 \pm 51$ \\
\hline milking & 9 & 1.76 & 1.39 & 1.78 & 1.41 & 1.88 & 2.10 & 2.50 & 2.40 & 2.25 & 2.16 & 8.06 \\
\hline $\begin{array}{l}\text { Irregular } \\
\text { milking }\end{array}$ & 9 & $\begin{array}{c}24.50 \pm \\
1.78\end{array}$ & $\begin{array}{c}29.28^{\mathrm{b}} \pm \\
1.41\end{array}$ & $\begin{array}{c}32.92 \pm \\
1.80\end{array}$ & $\begin{array}{c}32.58 \pm \\
1.43\end{array}$ & $\begin{array}{c}33.33 \pm \\
1.91\end{array}$ & $\begin{array}{c}33.98 \pm \\
2.13\end{array}$ & $\begin{array}{c}33.40 \pm \\
2.54\end{array}$ & $\begin{array}{c}32.88 \pm \\
2.43\end{array}$ & $\begin{array}{c}30.05 \pm \\
2.29\end{array}$ & $\begin{array}{c}28.12 \pm \\
2.19\end{array}$ & $\begin{array}{c}10187.45 \pm 5 \\
25.52\end{array}$ \\
\hline $\begin{array}{l}\text { Incomple } \\
\text { te } \\
\text { milking } \\
\text { Parity }\end{array}$ & 9 & $\begin{array}{c}27.18 \pm \\
1.62\end{array}$ & $\begin{array}{c}34.97^{\mathrm{a}} \pm \\
1.28\end{array}$ & $\begin{array}{c}35.51 \pm \\
1.63\end{array}$ & $\begin{array}{c}35.82 \pm \\
1.30\end{array}$ & $\begin{array}{c}35.22 \pm \\
1.73\end{array}$ & $\begin{array}{c}34.20 \pm \\
1.94\end{array}$ & $\begin{array}{c}34.18 \pm \\
2.30\end{array}$ & $\begin{array}{c}31.47 \pm \\
2.21\end{array}$ & $\begin{array}{c}29.20 \pm \\
2.07\end{array}$ & $\begin{array}{c}28.28 \pm \\
1.99\end{array}$ & $\begin{array}{c}10889.85 \pm 4 \\
76.73\end{array}$ \\
\hline number: & & $\begin{array}{c}21.66 \pm \\
4.83\end{array}$ & $\begin{array}{c}33.57 \pm 3 \\
82\end{array}$ & $\begin{array}{c}29.88 \pm \\
489\end{array}$ & $\begin{array}{c}28.65 \pm \\
3.89\end{array}$ & $\begin{array}{c}26.28 \pm \\
5.17\end{array}$ & $\begin{array}{c}26.56 \pm \\
579\end{array}$ & $\begin{array}{c}27.45 \pm \\
688\end{array}$ & $26.90 \pm$ & $27.64 \pm$ & $\begin{array}{c}28.83 \pm \\
5.94\end{array}$ & $8336.90 \pm 14$ \\
\hline $\begin{array}{l}\text { Second } \\
\text { Third }\end{array}$ & $\begin{array}{l}9 \\
9\end{array}$ & $\begin{array}{c}4.83 \\
27.30 \pm \\
2.07\end{array}$ & $\begin{array}{c}.82 \\
33.38 \pm 1 \\
.63\end{array}$ & $\begin{array}{c}4.89 \\
35.21 \pm \\
2.09\end{array}$ & $\begin{array}{c}3.89 \\
33.41 \pm \\
1.66\end{array}$ & $\begin{array}{c}5.17 \\
32.28 \pm \\
2.22\end{array}$ & $\begin{array}{c}5.79 \\
32.03 \pm \\
2.48\end{array}$ & $\begin{array}{c}6.88 \\
32.39 \pm \\
2.95\end{array}$ & $\begin{array}{c}6.60 \\
30.82 \pm \\
2.83\end{array}$ & $\begin{array}{c}6.20 \\
29.40 \pm \\
2.66\end{array}$ & $\begin{array}{c}5.94 \\
30.20 \pm \\
2.55\end{array}$ & $\begin{array}{c}23.11 \\
9725.25 \pm 61 \\
0.77\end{array}$ \\
\hline $\begin{array}{l}\text { Fourth or } \\
\text { more }\end{array}$ & 9 & $\begin{array}{c}29.31 \pm \\
6.13\end{array}$ & $\begin{array}{c}29.47 \pm 4 \\
.84\end{array}$ & $\begin{array}{c}37.21 \pm \\
6.20\end{array}$ & $\begin{array}{c}38.68 \pm \\
4.93\end{array}$ & $\begin{array}{c}41.11 \pm \\
6.56\end{array}$ & $\begin{array}{c}38.98 \pm \\
7.34\end{array}$ & $\begin{array}{c}37.84 \pm \\
8.72\end{array}$ & $\begin{array}{c}37.02 \pm \\
8.36\end{array}$ & $\begin{array}{c}30.92 \pm \\
7.86\end{array}$ & $\begin{array}{c}26.79 \pm \\
7.53\end{array}$ & $\begin{array}{c}12801.16 \pm 1 \\
804.52\end{array}$ \\
\hline
\end{tabular}

${ }^{\mathrm{a}, \mathrm{b}}$ Means within any classification, followed by different letters are significantly different $(\mathrm{p}<0.05)$.

ADMY $1-10=$ Average daily milk yield from $1^{\text {st }}$ to $10^{\text {th }}$ month of lactation.

$\mathrm{TMY}=$ Total milk yield during 10 months of lactation.

$\mathrm{N}=$ number of experimental cows

Table 3. Regression coefficient of the equation of wood lactation curve by drying off methods and parity number

\begin{tabular}{llll}
\hline \multicolumn{1}{c}{ Item } & $a(\mathrm{~kg})$ & $b$ & $c$ \\
\hline Drying off methods: & & & -0.02 \\
Sudden stop milking & $23.36^{\mathrm{b}}$ & 0.02 & -0.11 \\
Irregular milking & $27.54^{\mathrm{a}}$ & 0.41 & -0.07 \\
Incomplete milking & $27.55^{\mathrm{a}}$ & 0.58 & -0.12 \\
Parity number: & & & -0.18 \\
Second & $24.45^{\mathrm{b}}$ & 0.28 & -0.13 \\
Third & $25.46^{\mathrm{b}}$ & 0.32 & 0.41 \\
\hline Fourth or more & $28.47^{\mathrm{a}}$ & $0.41 \mathrm{c}$ & \\
\hline
\end{tabular}

Means within a column with different letters differ $(\mathrm{P}<0.05) ; a$ is the associated parameters with the initial milk production; $b$ is the associated parameter with the rise in milk production to peak lactation; $c$ is the associated parameter with the decrease

in milk production from peak to the end of lactation.

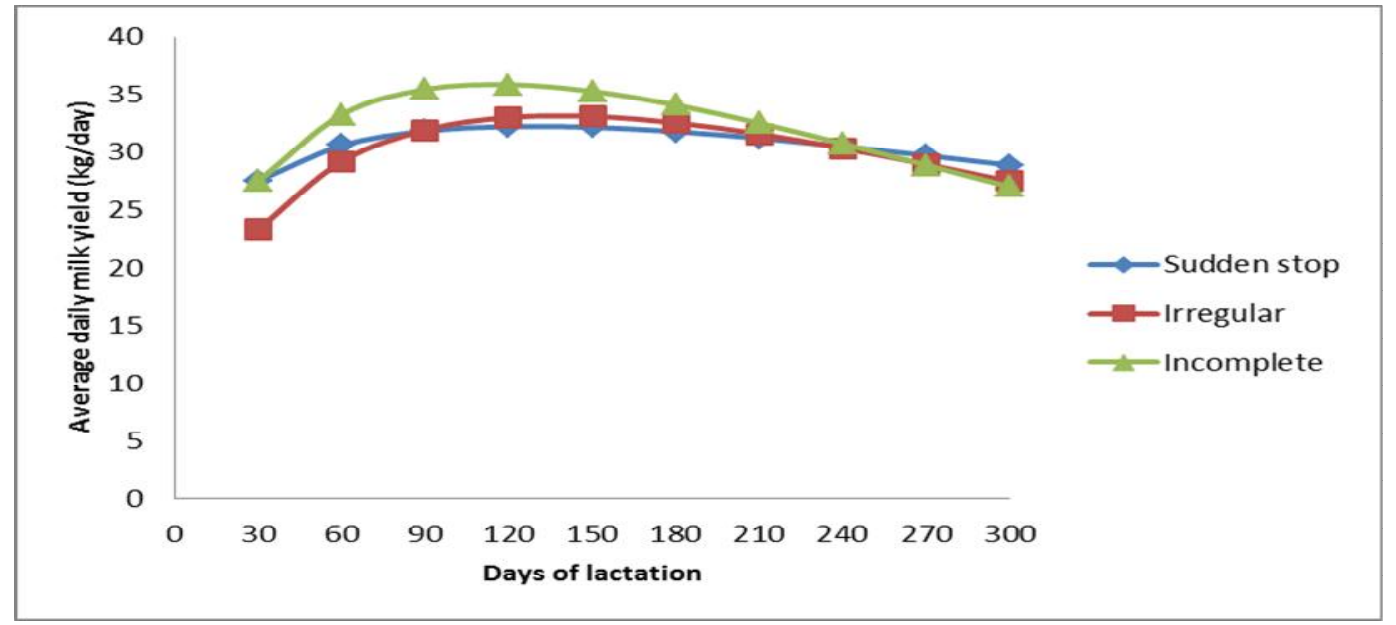

Figure 1. Drying off methods effect on average daily milk production during 300 days of lactation. 


\section{Parity number effect on milk production:}

It could be seen in Table 2 that fourth or more parity cows showed the highest milk production level $(12801.16 \mathrm{Kg})$ than other parities. The differences between means of cow's milk yield $(\mathrm{kg})$, due to parity effect, were non-significant. These results agree with those of Watter et al. (2008) who found that daily milk yield was 42.3 and $44.8 \mathrm{~kg}$, for Holstein cows at second and third or more parity, respectively, the same authors reported that differences between means of daily milk yield due to parity effect were not significant. Also, Santschi et al. (2011) reported that total milk yield of Holstein cows was 8580 and $10495 \mathrm{~kg}$, for cows at first and second or more parity, respectively, and the differences between means of total milk production due to parity effect were not significant. Mellado et al. (2014) using Holstein cows, reported that there were no differences between means of total milk yield due to parity number effect at first and second lactation (12707 versus $12306 \mathrm{~kg}$ ).

Parity number had affected $(\mathrm{P}<0.05)$ each of $a, b$ and c. Cows with higher parity number had higher a, $\mathrm{b}$ and $\mathrm{c}$ values than those with lower parity number. However, lactating cows with second parity have a lower initial production and rate of increase, than other parities (Table 3 and Figure 2). These results are in agreement with the finding of Yilmaz et al., (2011).

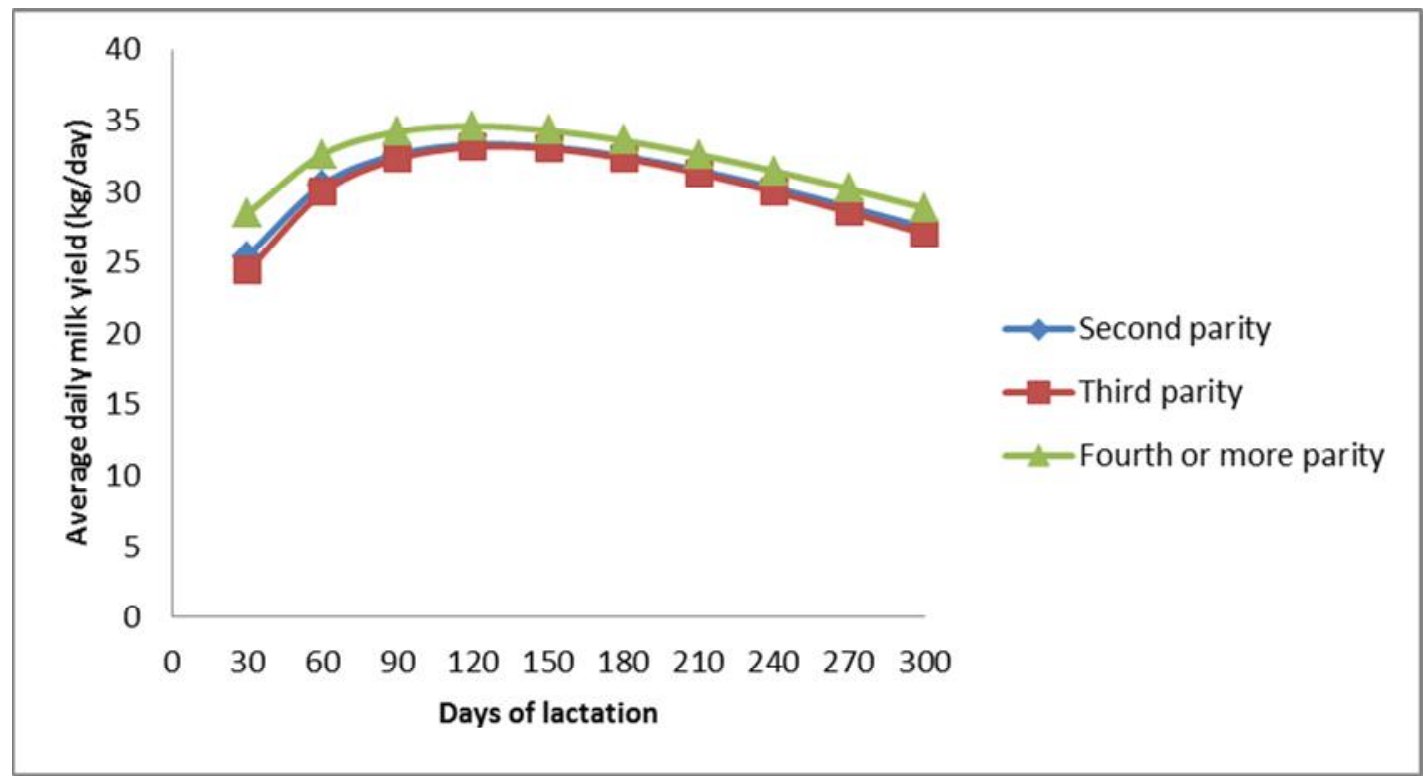

Figure 2. Parity number effect on average daily milk production during 300 days of lactation

The differences among means of experimental cow's average daily and total milk yield, due to the interaction between drying off methods and parity, were not significant.

\section{Significance of linear regression of milk yield on studied factors:}

The linear regression coefficients of experimental cow's milk yield on each of dry period length, cow's weight at dry period, cow's weight at calving and cow's weight after 50 days of lactation were not significant except for regression coefficient of daily milk yield at fourth month of lactation on cows weight at calving $(\mathrm{P}<0.05)$ and regression coefficients of daily milk yield at the third, fourth and fifth month of lactation on cows weight after 50 days of lactation $(\mathrm{P}<0.05$ and $\mathrm{P}<0.01)$.

\section{Milk composition of cows:}

\section{Drying off methods effect on milk composition:}

Cows that were dried off by the incomplete milking method had the highest milk composition of total solids, fat, solids not fat, protein and lactose $\%$ than other drying off methods (irregular milking and sudden stop milking methods, respectively) as shown in Table (4) and Figure (3). The differences between means of cow's milk composition, due to drying off methods effect, were highly significant $(\mathrm{P}<0.001)$ for all milk composition except for ash percentage.

Results obtained in the current study agree with those of Weglarzy (2009) who estimated that Holstein cow's milk fat percentage was $4.14,4.20$, 3.78 and $4.06 \%$, milk protein percent was $3.26,3.28$, 3.20 and $3.20 \%$, for cows with $<30,31-60,61-90$ and $>90$ days dry period, respectively. The same author stated that differences in milk protein production between groups were statistically significant $(\mathrm{P}<0.01)$ and fat production in group $<30$ days dry period was lower by $6.06 \%$, in group $>90$ days dry period lower by $5.37 \%$ in group $31-60$ days dry period lower by $1.01 \%$, protein production in group $<30$ days dry period was lower by $14.12 \%$, while, in group $>90$ days dry period and 31-60 days dry period lower by 12.84 and $9.78 \%$, respectively TOO LONG. Also, Pytlewski et al. (2009) found that the length of the dry period has a highly significant effect on yields of fat and protein content in Polish Holstein Friesian and Jersey cows. In addition, Santschi et al. (2011) 
reported that milk composition of Holstein cows was : fat percentage 3.86 and $3.92 \%$; protein percentage 3.31 and $3.40 \%$; lactose percentage 4.56 and $4.54 \%$, in cows at conventional dry period 60 days and short dry period 35 days, respectively. The same authors stated that there were no differences between means of milk composition due to dry period length, except for the protein percent $(\mathrm{P}<0.001)$. On the other hand, Wayne et al. (1933) did not record any significant difference in the quality of milk in the lactations following the drying up of cows by the three methods used (incomplete milking, intermittent milking and complete cessation).

Table 4. Least-squares means and standard errors for cow's milk composition

\begin{tabular}{lccccccc}
\multicolumn{1}{c}{ Classification } & $\mathbf{N}$ & $\begin{array}{c}\text { Total } \\
\text { solids\% }\end{array}$ & Fat\% & $\begin{array}{c}\text { Solids } \\
\text { not fat\% }\end{array}$ & Protein\% & Lactose\% & Ash\% \\
\hline Drying off methods: & & & & & & & \\
Sudden stop milking & 54 & $11.73^{\mathrm{c}} \pm 0.076$ & $3.25^{\mathrm{c}} \pm 0.034$ & $8.48^{\mathrm{c}} \pm 0.046$ & $3.09^{\mathrm{b}} \pm 0.031$ & $4.58^{\mathrm{b}} \pm 0.025$ & $0.800 \pm 0.01$ \\
& 54 & $12.08^{\mathrm{b}} \pm 0.076$ & $3.37^{\mathrm{b}} \pm 0.034$ & $8.70^{\mathrm{b}} \pm 0.046$ & $3.16^{\mathrm{b}} \pm 0.031$ & $4.74^{\mathrm{a}} \pm 0.025$ & $0.806 \pm 0.01$ \\
Irregular milking & 54 & $12.51^{\mathrm{a}} \pm 0.076$ & $3.57^{\mathrm{a}} \pm 0.034$ & $8.94^{\mathrm{a}} \pm 0.046$ & $3.29^{\mathrm{a}} \pm 0.031$ & $4.80^{\mathrm{a}} \pm 0.025$ & $0.831 \pm 0.01$ \\
Incomplete milking & & & & & & & \\
Parity number: & 54 & $11.70^{\mathrm{c}} \pm 0.076$ & $3.22^{\mathrm{c}} \pm 0.034$ & $8.47^{\mathrm{c}} \pm 0.046$ & $2.97^{\mathrm{c}} \pm 0.031$ & $4.69 \pm 0.025$ & $0.801 \pm 0.01$ \\
\hline Second & 54 & $12.16^{\mathrm{b}} \pm 0.076$ & $3.42^{\mathrm{b}} \pm 0.034$ & $8.74^{\mathrm{b}} \pm 0.046$ & $3.20^{\mathrm{b}} \pm 0.031$ & $4.73 \pm 0.025$ & $0.798 \pm 0.01$ \\
Third & 54 & $12.47^{\mathrm{a}} \pm 0.076$ & $3.55^{\mathrm{a}} \pm 0.034$ & $8.92^{\mathrm{a}} \pm 0.046$ & $3.37^{\mathrm{a}} \pm 0.031$ & $4.71 \pm 0.025$ & $0.837 \pm 0.01$ \\
Fourth or more & & & & & & & \\
Stage of lactation: & 54 & $11.56^{\mathrm{c}} \pm 0.08$ & $3.19^{\mathrm{c}} \pm 0.04$ & $8.36^{\mathrm{c}} \pm 0.05$ & $3.05^{\mathrm{c}} \pm 0.05$ & $4.56^{\mathrm{c}} \pm 0.02$ & $0.73^{\mathrm{c}} \pm 0.01$ \\
\hline First & 54 & $12.26^{\mathrm{b}} \pm 0.08$ & $3.45^{\mathrm{b}} \pm 0.04$ & $8.88^{\mathrm{b}} \pm 0.05$ & $3.21^{\mathrm{b}} \pm 0.05$ & $4.75^{\mathrm{b}} \pm 0.02$ & $0.82^{\mathrm{b}} \pm 0.01$ \\
Second & 54 & $12.55^{\mathrm{a}} \pm 0.09$ & $3.56^{\mathrm{a}} \pm 0.04$ & $9.98^{\mathrm{a}} \pm 0.05$ & $3.28^{\mathrm{a}} \pm 0.05$ & $4.81^{\mathrm{a}} \pm 0.02$ & $0.87^{\mathrm{a}} \pm 0.01$ \\
Third & &
\end{tabular}

${ }^{a}, b, c$ Means within any classification, followed by different letters are significantly different $(\mathrm{p}<0.05)$.

$\mathrm{N}=$ number of milk samples.

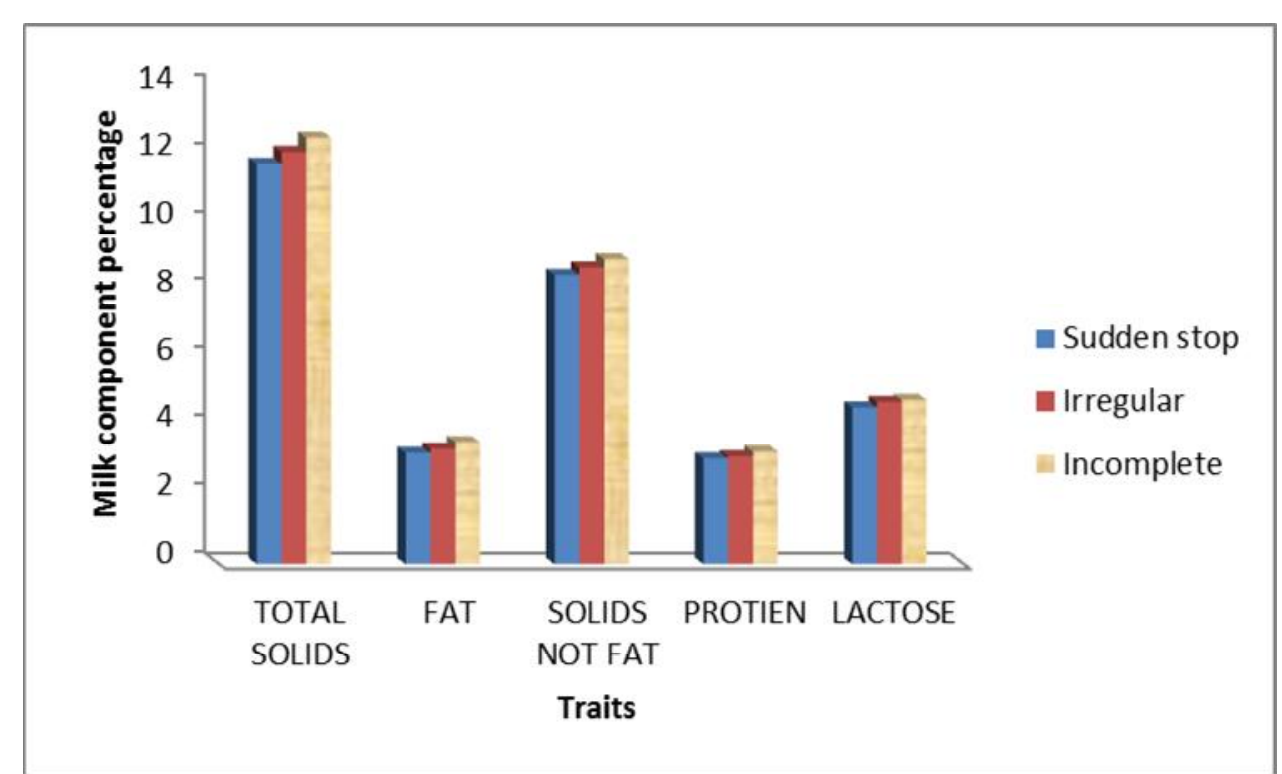

Figure 3. Effect of drying off method on milk composition

\section{Parity number effect on milk composition:}

Fourth or more parity cows had higher milk composition of total solids, fat, solids not fat and protein $\%$ compared with the second and third parties, respectively as shows in Table (4) and Figure (4). The differences between means of milk composition, due to the parity effect, were highly significant $(\mathrm{P}<0.001)$ for studied milk composition except for lactose and ash percentages.

The present results disagree with the finding of Santschi et al. (2011) who showed that Holstein cow's milk fat was 3.86 and $3.88 \%$; protein was 3.31 and $3.31 \%$; lactose was 4.56 and $4.45 \%$, for cows at second and third or more parity, respectively. The same authors reported that no significant differences between means of milk component, due to the parity number of cows and Steeneveld et al. (2014) who found that no significant differences between means of milk composition (fat and protein \%) due to parity of Holstein cows. Also, Van Knegsel et al. (2014) noticed that Holstein Friesian cow's milk protein and fat percentage doesn't affect by the parity number of cows except for lactose percentage $(\mathrm{P}<0.05)$.

Cows at third stage of lactation (last 100 days of lactation) had higher values of milk composition (total solids, fat, solids not fat, protein, lactose and ash\%) than cows at other stages of lactation (first 200 days of lactation) as shown in Table (4) and Figure (5). The differences between means of milk composition, due to stage of lactation effect, were 
highly significant $(\mathrm{P}<0.001)$. Similar results recorded by Soleimani et al. (2010) who found that Holstein cow's milk proteins, lactose and solids not fat $\%$ were affected by the week of lactation $(\mathrm{P}<0.001)$ but, milk fat $\%$ wasn't affected by the week of lactation and Steeneveld et al. (2014) who recorded that stage of lactation affected fat and protein\% of Dutch dairy cows milk $(\mathrm{P}<0.05)$. On the contrary, Safa et al. (2013) observed that Holstein cow's milk protein, lactose and solids not fat \% weren't affected by the week of lactation while, milk fat $\%$ affected by the week of lactation $(\mathrm{P}=0.0002)$.

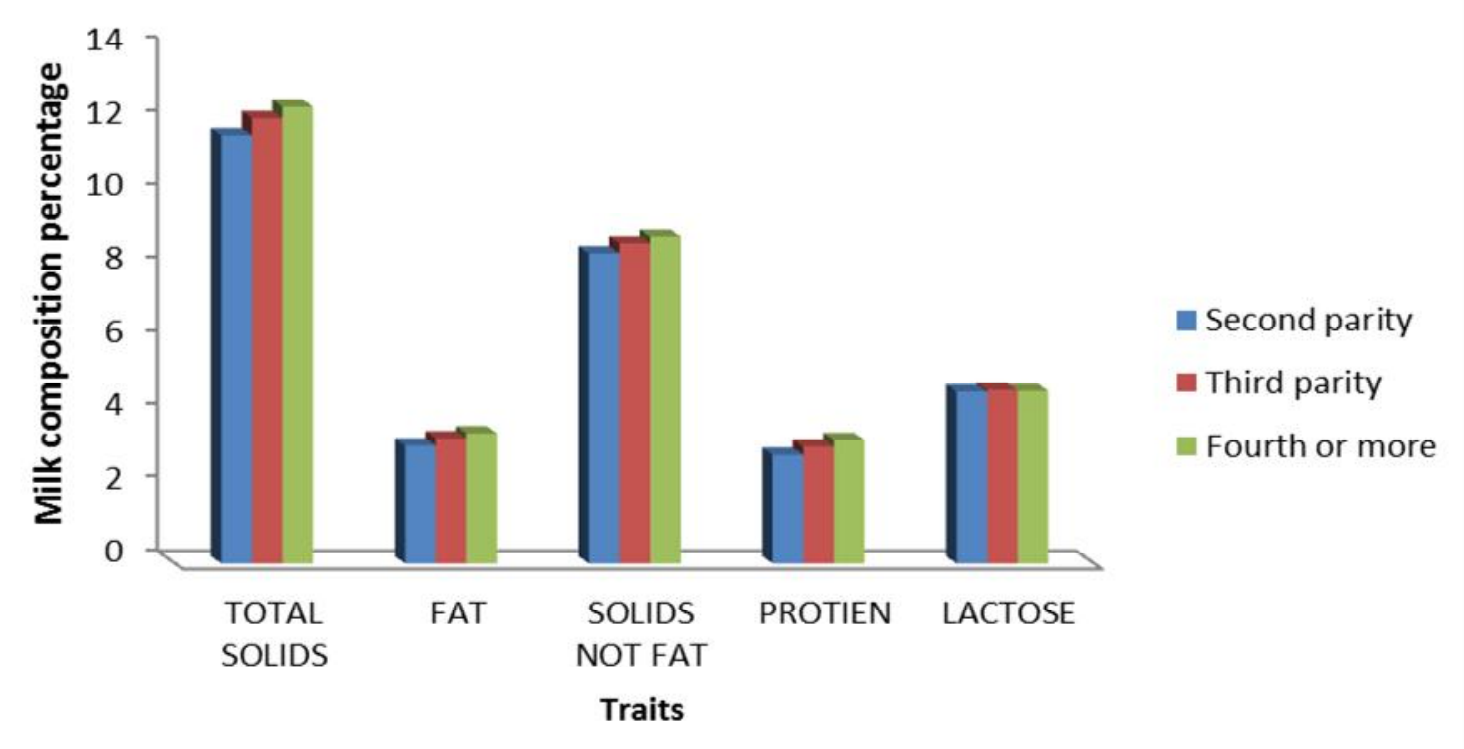

Figure 4. Effect of parity on milk composition(\%)

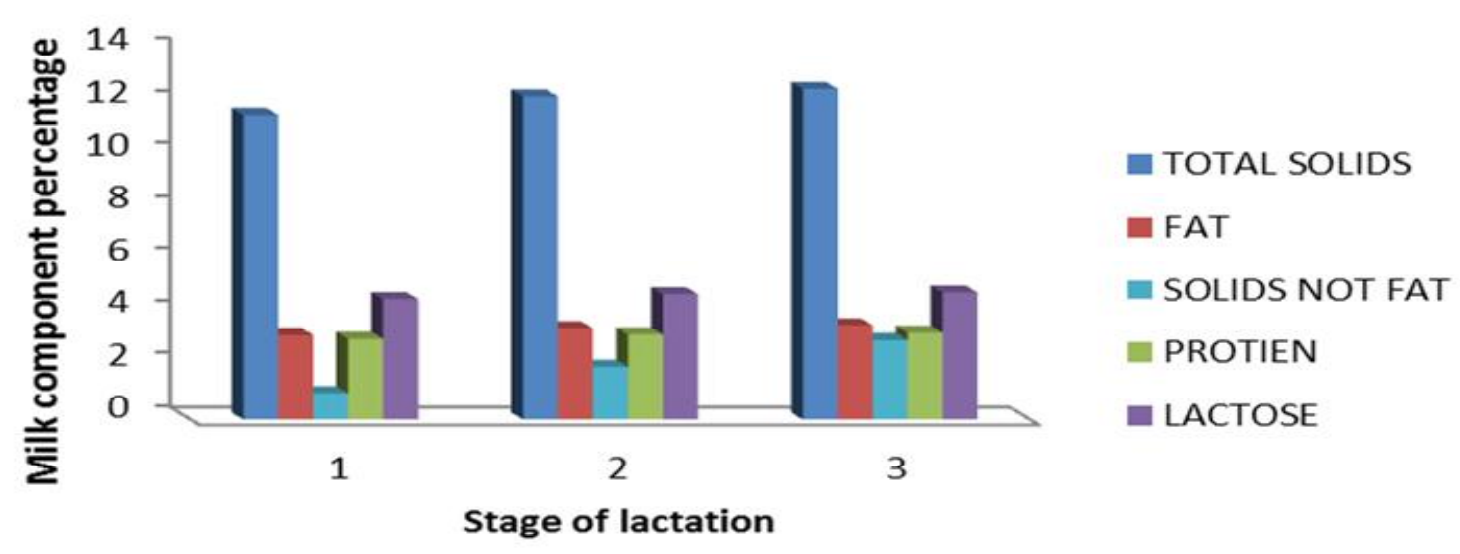

Figure 5. Effect of stage of lactation on milk composition (\%)

\section{Stage of lactation effect on milk composition:}

The differences among means of milk composition, due to the interaction among drying off methods, parity and stage of lactation, were not significant.

\section{Blood plasma parameters of cows: Drying off methods effect on blood plasma parameters:}

Means of cow's blood plasma parameters (total protein, albumin, globulin, $\mathrm{A} / \mathrm{G}$ ratio, triglyceride, total cholesterol, calcium, Potassium and magnesium) were almost the same value. The differences between means of blood plasma parameters, due to drying off methods effect, were not significant as presented in Table 5 and Figure 6 . Results obtained almost agree with those of Andersen et al. (2005) who showed that there were no overall effects of treatments (dry period of 60 days versus continuous lactation) on the blood plasma level of calcium $(\mathrm{P}=0.44)$. Also, Yamashina et al. (2012) observed that Holstein cow's blood plasma total protein and calcium were not affected by cows dry period length; total protein was 8.02 and $7.72 \mathrm{~g} / \mathrm{dl}$; calcium was 9.5 and $9.5 \mathrm{mg} / \mathrm{dl}$, for cows dried at short (40 days) and traditional (60 days) length, respectively. 
Table 5. Least-squares means and standard errors $(\mathrm{LSM} \pm \mathrm{SE})$ of cows blood plasma parameters

\begin{tabular}{|c|c|c|c|c|c|c|c|c|c|c|}
\hline Classification & $\mathbf{N}$ & $\begin{array}{l}\text { Total } \\
\text { Protein }\end{array}$ & Albumin & Globulin & $\begin{array}{l}\mathbf{A} / \mathbf{G} \\
\text { ratio }\end{array}$ & Triglyceride & Cholesterol & Calcium & Potassium & Magnesium \\
\hline \multicolumn{11}{|l|}{$\frac{\text { Drying off }}{\text { methods: }}$} \\
\hline Sudden stop & & $66.02 \pm$ & $31.80 \pm$ & $34.22 \pm$ & $0.929 \pm$ & $28.70 \pm$ & $157.88 \pm$ & $8.83 \pm$ & $5.84 \pm$ & $2.47 \pm$ \\
\hline milking & 54 & 0.299 & 0.159 & 0.146 & 0.001 & 0.127 & 1.85 & 0.033 & 0.035 & 0.032 \\
\hline Irregular & 54 & $66.38 \pm$ & $31.93 \pm$ & $34.43 \pm$ & $0.927 \pm$ & $28.80 \pm$ & $154.51 \pm$ & $8.83 \pm$ & $5.80 \pm$ & $2.50 \pm$ \\
\hline milking & 54 & 0.299 & 0.159 & 0.146 & 0.001 & 0.127 & 1.85 & 0.033 & 0.035 & 0.032 \\
\hline Incomplete & 54 & $66.30 \pm$ & $31.94 \pm$ & $34.39 \pm$ & $0.928 \pm$ & $28.67 \pm$ & $158.25 \pm$ & $8.89 \pm$ & $5.83 \pm$ & $2.57 \pm$ \\
\hline $\begin{array}{l}\text { milking } \\
\text { Parity }\end{array}$ & 54 & 0.299 & 0.159 & 0.146 & 0.001 & 0.127 & 1.85 & 0.033 & 0.035 & 0.032 \\
\hline number: & & $65.75 \pm$ & $31.63 \pm$ & $34.12 \pm$ & $0.926 \pm$ & $28.52 \pm$ & $152.59^{\mathrm{b}} \pm$ & $8.82 \pm$ & $5.75^{\mathrm{b}} \pm$ & $2.42^{\mathrm{b}} \pm$ \\
\hline$\overline{\text { Second }}$ & 54 & 0.299 & 0.159 & 0.146 & 0.001 & 0.127 & 1.85 & 0.033 & 0.035 & 0.032 \\
\hline Third & 54 & $\begin{array}{l}66.48 \pm \\
0.299\end{array}$ & $\begin{array}{l}32.02 \pm \\
0.159\end{array}$ & $\begin{array}{l}34.47 \pm \\
0.146\end{array}$ & $\begin{array}{l}0.928 \pm \\
0.001\end{array}$ & $\begin{array}{l}28.87 \pm \\
0.127\end{array}$ & $\begin{array}{l}157.37^{\mathrm{ab}} \pm \\
1.85\end{array}$ & $\begin{array}{l}8.85 \pm \\
0.033\end{array}$ & $\begin{array}{l}5.83^{\mathrm{ab}} \pm \\
0.035\end{array}$ & $\begin{array}{l}2.53^{\mathrm{a}} \pm \\
0.032\end{array}$ \\
\hline $\begin{array}{l}\text { Fourth or } \\
\text { more } \\
\text { Stage of }\end{array}$ & 54 & $\begin{array}{l}66.46 \pm \\
0.299\end{array}$ & $\begin{array}{l}32.03 \pm \\
0.159\end{array}$ & $\begin{array}{l}34.45 \pm \\
0.146\end{array}$ & $\begin{array}{l}0.929 \pm \\
0.001\end{array}$ & $\begin{array}{l}28.78 \pm \\
0.127\end{array}$ & $\begin{array}{l}160.68^{\mathrm{a}} \pm \\
1.85\end{array}$ & $\begin{array}{l}8.88 \pm \\
0.033\end{array}$ & $\begin{array}{l}5.88^{\mathrm{a}} \pm \\
0.035\end{array}$ & $\begin{array}{l}2.59^{\mathrm{a}} \pm \\
0.032\end{array}$ \\
\hline lactation: & & $65.59^{\mathrm{c}} \pm$ & $31.62^{\mathrm{c}} \pm$ & $33.96^{\mathrm{c}} \pm$ & $0.93 \pm$ & $28.54 \pm$ & $157.98 \pm$ & $8.86 \pm$ & $5.85 \pm$ & $2.49 \pm$ \\
\hline First & 54 & 0.41 & 0.22 & 0.19 & 0.002 & 0.17 & 2.64 & 0.047 & 0.051 & 0.046 \\
\hline Second & 54 & $\begin{array}{l}66.04^{\mathrm{b}} \pm \\
0.41\end{array}$ & $\begin{array}{l}31.73^{\mathrm{b}} \pm \\
.22\end{array}$ & $\begin{array}{l}34.29^{\mathrm{b}} \pm \\
0.19\end{array}$ & $\begin{array}{l}0.92 \pm \\
0.002\end{array}$ & $\begin{array}{l}28.88 \pm \\
0.17\end{array}$ & $\begin{array}{l}155.87 \pm \\
2.64\end{array}$ & $\begin{array}{l}8.87 \pm \\
0.047\end{array}$ & $\begin{array}{l}5.84 \pm \\
0.051\end{array}$ & $\begin{array}{l}2.50 \pm \\
0.046\end{array}$ \\
\hline Third & 54 & $\begin{array}{l}67.13^{\mathrm{a}} \pm \\
0.42\end{array}$ & $\begin{array}{l}32.35^{\mathrm{c}} \pm \\
0.22\end{array}$ & $\begin{array}{l}34.81^{\mathrm{a}} \pm \\
0.20\end{array}$ & $\begin{array}{l}0.93 \pm \\
0.002\end{array}$ & $\begin{array}{l}28.78 \pm \\
0.18\end{array}$ & $\begin{array}{l}156.40 \pm \\
2.74\end{array}$ & $\begin{array}{l}8.80 \pm \\
0.049\end{array}$ & $\begin{array}{l}5.76 \pm \\
0.053\end{array}$ & $\begin{array}{l}2.51 \pm \\
0.048\end{array}$ \\
\hline
\end{tabular}

${ }^{a, b, c}$ Means within any classification, followed by different letters are significantly different $(\mathrm{p}<0.05)$.

$\mathrm{N}=$ number of blood samples

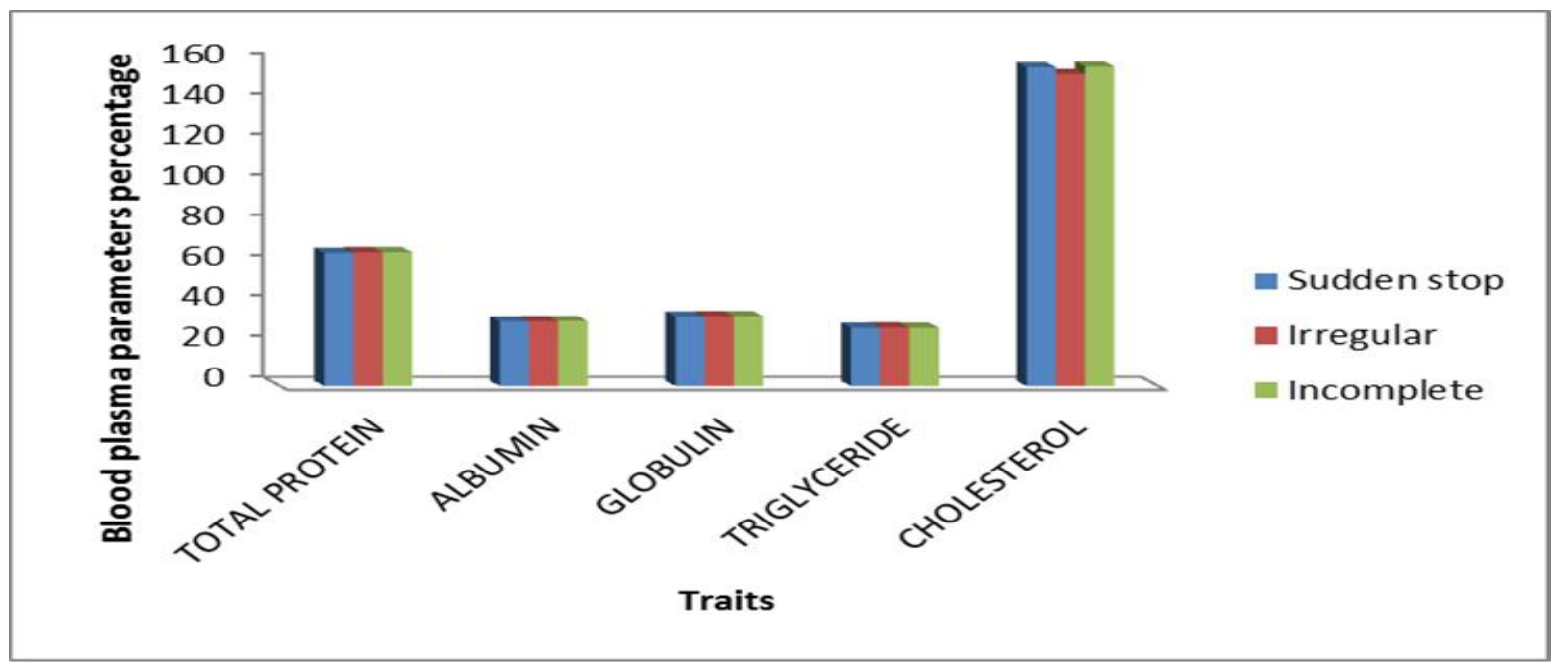

Figure 6. Effect of drying off methods on blood plasma parameters

Effect of parity on blood plasma parameters:

Fourth or more parity cows had the highest means of cholesterol, potassium and magnesium in cows blood plasma while, second parity cows had the lowest means of cholesterol, potassium and magnesium in cows blood plasma. There were no differences between means of blood plasma parameters (total protein, globulin, albumin, $\mathrm{A} / \mathrm{G}$ ratio, triglyceride and albumin), due to parity effect except for cholesterol, potassium and magnesium means which were significant $(\mathrm{P}<0.01)$ as showed in Table 5 and Figure 7. The opposite results were obtained by, Cozzi et al. (2011) who found that serum total protein and globulin of Holstein dairy cows were 80 and $43 \mathrm{~g} / \mathrm{L}$, for first parity cows, while it were 83 and $45 \mathrm{~g} / \mathrm{L}$, for second or more parity cows, respectively; there was no significant effect of parity on blood serum total protein and globulin of cows. On the contrary, Brscic et al. (2015) using Holstein cows, found that blood serum total protein and globulins were 77.1 and $40.9 \mathrm{~g} / \mathrm{L}$, for first parity cows, while, it was 81.3 and $44.3 \mathrm{~g} / \mathrm{L}$, for first and second or more parity cows, respectively, and differences between means of cows blood serum total protein and globulins due to parity effect were significant $(\mathrm{P}<0.05)$. 


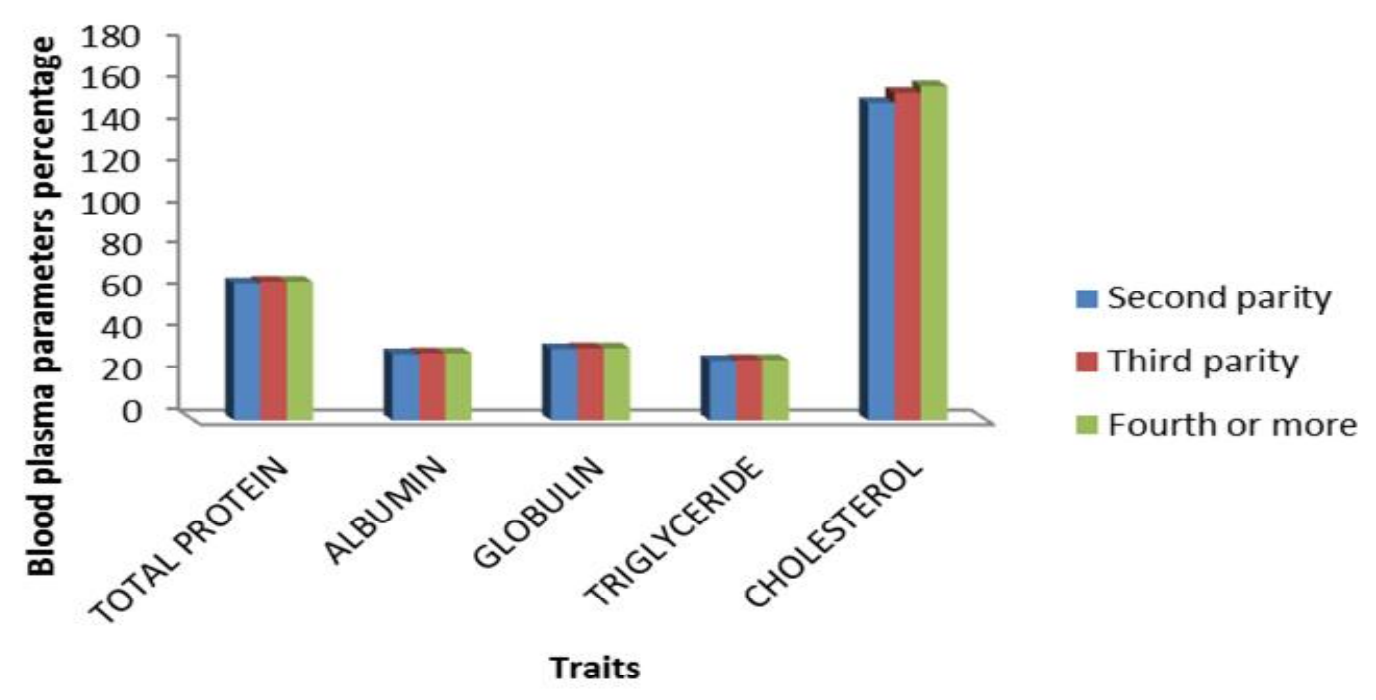

Figure 7. Effect of parity on some blood plasma parameters

\section{Stage of lactation effect on blood plasma parameters:}

Cows in the last lactation stage (last 100 days of lactation) had higher values of cow's blood plasma protein, globulin and albumin than cows in other lactation stages and cows in the first lactation stage (first 100 days of lactation) had the lower values as shown in Table 5 and Figure 8. The differences between means of blood plasma total protein, globulin and albumin, due to stage of lactation effect, were significant $(\mathrm{P}<0.05$ and $\mathrm{P}<0.01)$ but, for other cows blood plasma parameters were not significant. Similar results obtained by Cozzi et al. (2011) who recorded that blood serum cholesterol of Holstein dairy cows was 4.9 and $5.9 \mathrm{mmol} / \mathrm{L}$, for cows at early and medium stage of lactation, respectively; there were no differences between means of cows blood serum cholesterol due to stage of lactation effect and Brscic et al. (2015) using Holstein cows, stated that blood serum total protein was $77.7,78.4$ and $74.8 \mathrm{~g} / \mathrm{L}$; globulin was $41.1,42.0$ and $38.7 \mathrm{~g} / \mathrm{L}$, for cows at 10 20, 21-40 and 41-60 days of lactation, respectively, differences between means of cows blood serum total protein and globulin due lactation stage effect were significant $(\mathrm{P}<0.05)$. Also, Yamashina et al. (2012) indicated that blood plasma total protein and albumin of Holstein cows were affected by stage of lactation postpartum $(\mathrm{P}<0.01)$, total protein was $7.59,8.25$ and $8.81 \mathrm{~g} / \mathrm{dl}$, albumin was $3.47,3.64$ and $3.79 \mathrm{~g} / \mathrm{dl}$, for cows at 1,3 and 10 weeks postpartum, respectively.

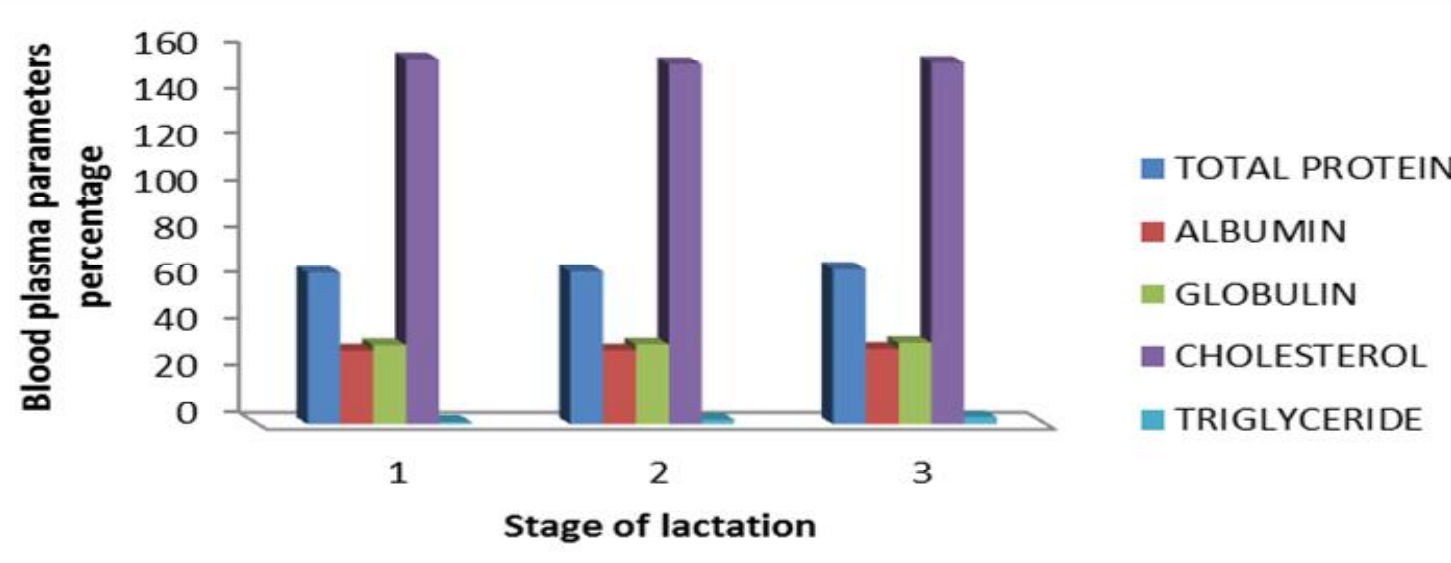

Figure 8. Effect of stage of lactation on some blood plasma parameters.

The differences among means of blood plasma parameters, due to the interaction among drying off methods, parity and stage of lactation, were not significant.

\section{CONCLUSION}

As a conclusion, incomplete, irregular and sudden stop milking can safely be recommended as a method for drying off cows producing at least up to 20, 11-20 and $>10 \mathrm{~kg}$ daily, respectively without negative results in quantity and quality of milk as well as blood plasma parameters. 


\section{RECOMMENDATIONS}

It could be recommend that using sudden stop method for low lactating cows (less than $10 \mathrm{~kg}$ milk/day) and irregular and incomplete methods for both medium and high lactating cows (11-20 kg and more than $20 \mathrm{~kg}$ milk/day, respectively).

\section{REFERENCES}

Abdel-Salam, S.A.M., W. Mekkawy, Y.M. Hafez, A.A. Zaki and S. Abou-Bakr, 2011. Fitting lactation curve of Egyptian buffalo using three different models. Egyptian J. Anim. Prod., 48(2):119-133.

American Association for Clinical Chemistry, 1977. Pediatric Clinical Chemistry (S. Meites, Ed) Washington, D. C., P.240.

Andersen J. B., T. G. Madsen, T. Larsen, K. L. Ingvartsen and M. O. Nielsen, 2005.The Effects of Dry Period Versus Continuous Lactation on Metabolic Status and Performance in Periparturient Cows. Journal Dairy Science Vol. 88:3530-3541.

AOAC, 1995. Official Methods of Analysis. 15th Association of Official Analytical Chemists Washington, D. C.

Atashi H., M. J. Zamiri and M. Dadpasand, 2013. Association between dry period length and lactation performance, lactation curve, calf birth weight, and dystocia in Holstein dairy cows in Iran. Journal Dairy Science Vol. 96:3632-3638.

Brscic M., G. Cozzi, I. Lora, A. L. Stefani, B. Contiero, L. Ravarotto and F. Gottardo, 2015. Reference limits for blood analytes in Holstein late-pregnant heifers and dry cows: Effects of parity, days relative to calving, and season. Journal Dairy Science Vol. 98:7886-7892.

Cozzi G., L. Ravarotto, F. Gottardo, A. L. Stefani, B. Contiero, L. Moro, M. Brscic and P. Dalvit, 2011. Reference values for blood parameters in Holstein dairy cows: Effects of parity, stage of lactation, and season of production. Journal Dairy Science Vol. 94:3895-3901.

Dingwell R. T., D. F. Kelton, K. E. Leslie and V. L. Edge, 2001. Deciding to dry-off: Does level of production matter? National Mastitis Council Annual Meeting Proceedings 10:69-79.

Doums, B.T.; W.A. Watson and H.S. Bigges, 1971. Albumin standard and measurement of serum albumin with bromocresol green. Clin. Chem. Acta., 31:87-96.

Duncan D. B., 1955. Multiple ranges and multiple Ftest. Biometrics 11:1-42.

Frings C. S., T. W. Fendly, R. T. Dunn and C. A. Queen, 1972. Improved determination of total serum lipids by the sulfophosphoalanine reaction. Clinical Chemistry, 18, 673-679.

Henry R.J., 1964. Clinical chemistry . Harper and Publishers, New York.P.181.

IDF, 1991a. International Dairy Federation, Milk and milk products Determination of fat content.
General Guidance on the Use of Butyrometric Methods IDF:151.

IDF, 1991b. International Dairy Federation, Yoghurt: Determination of total solides content. IDF:151.

IDF, 1993. International Dairy Federation, Milk: Determination of nitrogen content. IDF:20B.

Kuhn M. T., J. L. Hutchison, and H. D. Norman, 2007. Dry Period Length in US Jerseys: Characterization and Effects on Performance. Journal Dairy Science Vol. 90:2069-2081.

Mellado Jesus, Sepulveda Edgar, Garcia Jose E., Rodriguez Alvaro, De Santiago Maria A, Veliz Francisco G. and Mellado Miguel, 2014. Milk yield of Holstein cows induced into lactation twice consecutively and lactation curve models fitted to artificial lactations. Journal of Integrative Agriculture. Vol.13(6):1349-1354.

NRC, 2001. Nutrient Requirement of Dairy Cattle. 7 th rev. ed. National Academy Press, Washington, DC.

Pytlewski J., I. Antkowiak, R. Skrzypek, K.Kesy, 2009.The effect of dry period length on milk performance traits of black and white Polish Holstein-Friesian and Jersey cows. Annals of Animal Science, Vol. 9, No. 4:341-353.

Safa S., A. Soleimani and A. Heravi Moussavi, 2013. Improving Productive and Reproductive Performance of Holstein Dairy Cows through Dry Period Management. Asian Australian Journal of Animal Science Vol. 26, No. 5: 630-637.

Santschi D. E., D. M. Lefebvre, R. I. Cue, C. L. Girard and D. Pellerin, 2011. Complete -lactation milk and component yields following a short (35d) or a conventional (60-d) dry period management strategy in commercial Holstein herds. Journal Dairy Science Vol. 94:2302-2311.

SAS, 2004. SAS Procedure Guide "version 9 Ed". SAS Institute Inc., Cary, NS, USA.

Soleimani Akbar, Moussavi Heravi Alireza, Mesgaran Mohsen Danesh, Golian Abolqasem, 2010. Effects of Dry Period Length on Milk Production and Composition, Blood Metabolites and Complete Blood Count in Subsequent Lactation of Holstein Dairy Cows. International Journal of Biological, Biomolecular, Agricultural, Food and Biotechnological Engineering, Vol:4, No:8, P:486-491.

Steeneveld W., A. T. M. Van Knegsel, G. J. Remmelink, B. Kemp, J. C. M. Vernooij and H. Hogeveen, 2014. Cow characteristics and their association with production performance with different dry period lengths. Journal Dairy Science Vol. 97:4922-4931.

Useni B.A., C.J.C. Muller and C.W. Cruywagen, 2014. Milk production of dairy cows as affected by the length of the preceding dry period. South African Journal of Animal Science Vol. 44 (Issue 5, Supplement.1):21-24.

Van Knegsel A. T. M., G. J.Remmelink, S. Jorjong, V. Fievez, and B. Kemp, 2014. Effect of dry period length and dietary energy source on energy balance, milk yield, and milk composition of 
dairy cows. Journal Dairy Science Vol. 97:14991512.

Watters R. D., J. N. Guenther, A. E. Brickner, R. R. Rastani, P. M. Crump, P. W. Clark, and R. R. Grummer, 2008. Effects of Dry Period Length on Milk Production and Health of Dairy Cattle. Journal Dairy Science. Vol. 91:2595-2603.

Wayne R., C. H. Eckles and W. E. Peterson, 1933. Drying up cows and the effect of different methods upon milk production. Journal of dairy science Vol. 16 Issue1, Pages 69-78.

Węglarzy Karol, 2009. Lactation productivity of dairy cows as affected by the length of preceding dry period. Animal Science Papers and Reports Vol. 27 No. 4:303-310.

Wood P.D.P., 1967. Algebraic model of the lactation curve in cattle. Nature, 216:164-165.

Yamashina Kazuki, Yoshimura Yoshihisa, Ikuta Kentaro, Maruyama Asako, Muranaka Hiromi,
Tokita Yasuhiro, Katoh Kazuo, Takusari Naozumi and Terada Fuminori, 2012. Effects of a 40 day dry period on lactation performances, reproductive measures, and health parameters in Holstein cows. Nihon Chikusan Gakkaiho. Vol. 83(4):363-372.

Yilmaz I., E. Eyduran, A. Kaygisiz and K. Javed, 2011. Estimates of genetic parameters for lactation shape parameters with multivariate statistical technique in brown swiss cattle. International Journal of Agricuture and Biology. 13: $174-178$

Zadeh Ghavi Hossein N. and A. Mohit, 2013. Effect of dry period length on the subsequent production and reproduction in Holstein cows. Spanish Journal of Agricultural Research.Vol. 11(1):100108.

\section{تأثير طرق التجفيف وترتيب الولادة ومرحلة الإدرار على انتاج اللبن ومكوناته وبعض تقديرات بلازما الام فى أبقار الهولثتاين فريزيان}

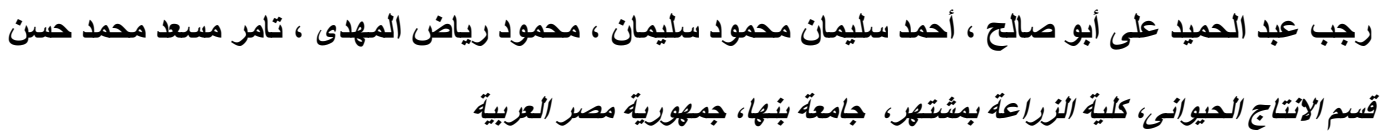

الهدف من الدر اسة بحث تأثتر طرق التجفيف وترتيب الو لادة ومرحلة الادرار على انتاج اللبن ومكوناته وبعض تقديرات بلازما

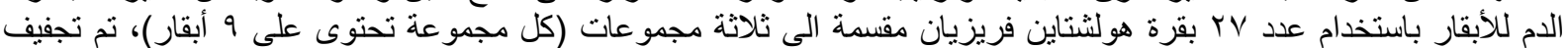

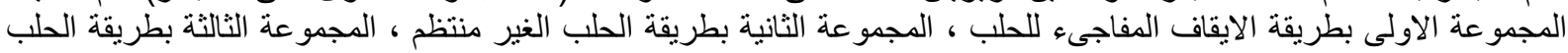

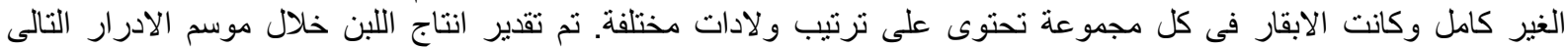

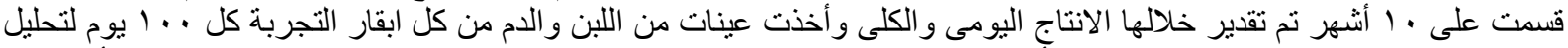

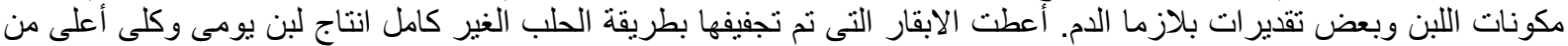

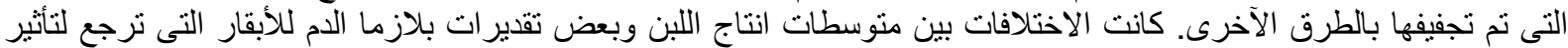

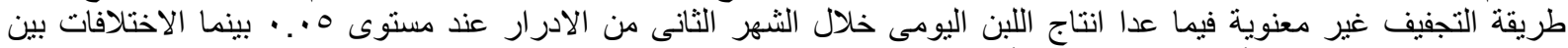

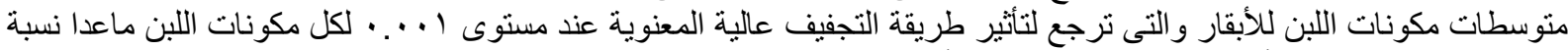

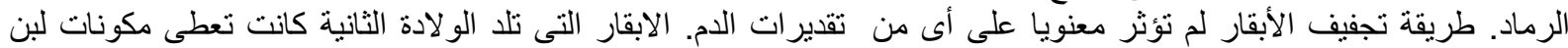

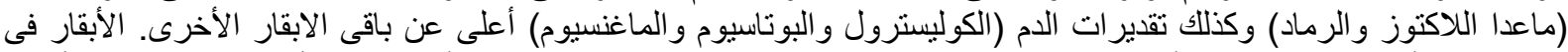

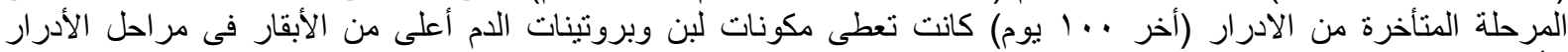

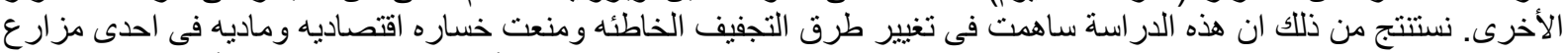

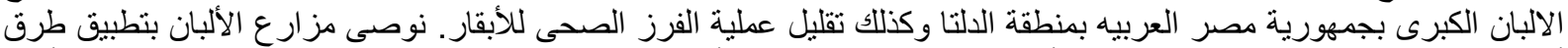

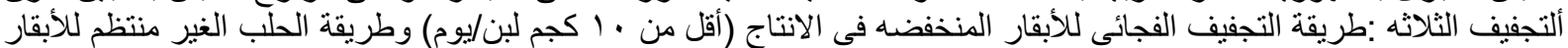

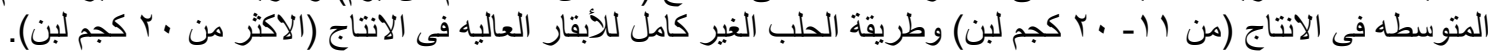


Egyptian J. Anim. Prod. (2017) 54(1):19-29 